\title{
Taeniasis Solium dan Sistiserkosis pada Manusia
}

\author{
Elva Susanty*
}

\begin{abstract}
Taenia solium (taeniasis) and cysticercosis in human are infectious diseases caused by pork tapeworm Taenia solium. They are zoonotic diseases and still a health problem in the world, especially in developing countries such as Indonesia. The prevalence of taeniasis and cysticercosis in Indonesia is still quite high at $2 \%-48 \%$ with the highest prevalence in Papua. Human taeniasis can manifest as a asymptomatic or intestinal minimally symptomatic. Cysticercosis can involve of neural tissue (neurocysticercosis) may manifest epilepsy seizure, headache, neurological symptom, cognitive disabilities, and death. The habit of eating raw or undercooked pork, lack of sanitation, and a lack of supervision the slaughterhouse are some of the factors causing taeniasis and cysticercosis in human. Avoiding eating raw pork, cooking meat over temperature $54^{\circ} \mathrm{C}$, supervision at slaughterhouses, and maintaining hygiene is a way to prevent taeniasis and cysticercosis, therefore it is necesarry to do more intensive programs to prevent and control the diseases.
\end{abstract}

Keywords: taeniasis, cysticercosis, Taenia solium, zoonotic disease

Taeniasis solium (taeniasis) dan sistiserkosis dikategorikan sebagai neglected tropical diseases (NTDs) atau neglected zoonotic diseases (NZDs) yang disebabkan oleh cacing pita Taenia solium ( $T$. solium $)^{1}$ dan masih menjadi masalah kesehatan di dunia khususnya di negara berkembang. ${ }^{2}$ Tingginya mobilitas migrasi penduduk dari negara endemik ke negara maju (negara industri) menyebabkan kompleksnya pola penyebaran taeniasis dan sistiserkosis, sehingga menjadi permasalahan kesehatan di seluruh dunia. ${ }^{1}$ Manusia mendapat infeksi taeniasis disebabkan karena memakan daging babi mentah atau tidak matang yang mengandung sistiserkus hidup. ${ }^{3}$ Infeksi ini sering dijumpai di daerah yang masyarakatnya mempunyai kebiasaan mengkonsumsi daging babi mentah/setengah matang $^{2}$ dan jarang ditemukan di negara Islam. ${ }^{4}$

Hospes defenitif Taenia solium adalah manusia ${ }^{4,5}$ sedangkan hospes perantaranya adalah babi $^{4,6}$ dan manusia. ${ }^{4}$ Taeniasis yang disebabkan oleh infeksi T. solium dewasa ${ }^{7}$ dapat menimbulkan

\footnotetext{
* Penulis untuk korespondensi : *KJF Parasitologi Fakultas Kedokteran Universitas Riau, Pekanbaru Email Korespondensi : kaylaelva@gmail.com
}

gangguan pencernaan, diare, konstipasi, tetapi dapat juga asimptomatis (tanpa gejala). ${ }^{8}$ Sistiserkosis pada manusia umumnya disebabkan infeksi oleh larva $T$. solium $^{7}$ yang dapat mengenai otot dan sistem saraf pusat (SSP) ${ }^{4}$ disebut dengan neurosistiserkosis yang dapat menimbulkan kejang epilepsi, sakit kepala, gejala neurologik, sampai kematian. ${ }^{9}$

Taeniasis dan sistiserkosis merupakan penyakit endemik terutama terjadi di negara berkembang seperti Afrika, Timur Tengah, Eropa Barat, Meksiko, Amerika Tengah, Amerika Selatan, dan Asia diantarnya yaitu: Korea, Cina, Filipina termasuk Indonesia. ${ }^{8,10}$ Daerah di Indonesia yang banyak ditemukan infeksi ini adalah di Bali, Papua, dan Pulau Samosir Sumatera Utara. Laporan Simanjuntak et al dalam Sandy ${ }^{5}$, menunjukkan bahwa prevalensi taeniasis dan sistiserkosis di Indonesia berkisar 2-48 \%, dengan daerah Papua sebagai prevalensi tertinggi.

Tulisan ini merupakan kajian dari beberapa studi kepustakaan dan artikel jurnal yang terkait dengan penyakit taeniasis dan sistiserkosis di Indonesia dan beberapa negara yang terjadi kasus tersebut. 


\section{ETIOLOGI DAN MORFOLOGI}

Taeniasis adalah infeksi pada saluran pencernaan yang disebabkan oleh cacing pita (cestoda) dari genus Taenia sp seperti Taenia solium, ${ }^{5,6,7}$ sedangkan sistiserkosis merupakan penyakit yang disebabkan oleh infeksi larva dari Taenia sp biasanya disebabkan oleh larva Taenia solium. ${ }^{11}$ Taenia solium adalah parasit dalam usus halus manusia ${ }^{8,12}$ yang dapat mencemari lingkungan dengan telur atau proglotidnya apabila sanitasi tidak memadai. ${ }^{12}$ Taenia solium berbentuk panjang, ${ }^{3,4}$ bersegmen $^{3}$, dan terdiri dari kepala yang disebut skoleks, leher, dan strobila yang merupakan rangkaian ruas-ruas proglotid ${ }^{4}$ dan ada yang dapat hidup sampai 25 tahun. ${ }^{3}$ Taenia solium dewasa memiliki panjang 2-8 $\mathrm{m}^{11}$ dan memiliki alat penghisap dengan kait pada skoleksnya, ${ }^{4,13}$ yang berbentuk bulat berukuran kirakira 1 milimeter dan mempunyai 4 buah batil isap. ${ }^{4}$

\section{DISTRIBUSI GEOGRAFIK}

Penyebaran taeniasis dan sistiserkosis bersifat kosmopolitan, tersebar luas di seluruh dunia, khususnya terutama di negara yang sedang berkembang seperti Afrika, Amerika Tengah, Amerika Selatan, dan Asia termasuk Indonesia di daerah yang penduduknya senang makan daging babi mentah atau setengah matang. ${ }^{12}$ Sistiserkosis, terutama yang disebabkan oleh Taenia solium biasanya ditemukan di Amerika Latin, Asia Tenggara dan Afrika, sangat jarang di negara muslim. ${ }^{3}$

Mobilitas penduduk dunia yang tinggi seperti turis manca negara dan ekspansi bisnis, menyebabkan penyakit ini juga ditemukan di daerah yang keadaan ekonominya sudah baik ${ }^{6,12}$ atau negara maju seperti di Amerika Serikat yang disebabkan karena meningkatnya jumlah imigran dari Meksiko dan negara berkembang lainnya ke Amerika Serikat. ${ }^{6,14}$ Diperkirakan 2,5 juta orang terinfeksi $T$. solium, dan sekitar 5.000 kematian setiap tahun disebabkan oleh sistiserkosis. ${ }^{9}$ Penderita sistiserkosis di Eropa juga mengalami peningkatan dikarenakan datangnya imigran dari negara berkembang ke Eropa sebesar $74,7 \%$ dan turis manca negara sebesar $17,6 \%{ }^{11}$

Taeniasis solium dan sistiserkosis di Indonesia terutama ditemukan di tiga propinsi yaitu Sumatera Utara, Bali, dan Irian Jaya. ${ }^{15}$ Penyakit tersebut juga ditemukan di Lampung, Sulawesi Utara, Sulawesi Tenggara, Nusa Tenggara Timur, dan Kalimantan Barat ${ }^{12}$ dengan Propinsi Papua adalah daerah yang hiperendemis sistiserkosis. ${ }^{14}$ Prevalensi sistiserkosis pada manusia di Propinsi Papua adalah di daerah pedesaan Kabupaten Jayawijaya sebesar 41,3\%66,7\% disebabkan karena masyarakat di daerah tersebut lebih mudah bermigrasi sehingga memudahkan penularan taeniasis dan sistiserkosis. ${ }^{5,14}$ Masih tingginya prevalensi taeniasis dan sistiserkosis di daerah Papua disebabkan karena masih rendahnya tingkat pendidikan, sanitasi lingkungan dan kebersihan diri yang masih kurang, tingkat pengetahuan terhadap penyakit tersebut masih kurang, sosial ekonomi-budaya yang berbedabeda, dan cara memelihara hewan ternak yang masih tradisional (tidak dikandangkan) menyebabkan penyakit ini masih tetap ada di daerah tersebut. ${ }^{8}$

Menurut Kosin dalam Subahar et al, ${ }^{14}$ taeniasis merupakan penyakit keluarga sehingga pada daerah endemis apabila ada seorang anggota keluarga menderita taeniasis maka ada kemungkinan ditemukannya anggota keluarga lain yang menderita taniasis solium dan/atau sistiserkosis. Hasil penelitian yang dilakukan oleh Sorvillo et al, ${ }^{16}$ pada keluarga penderita taeniasis solium/sistiserkosis menunjukkan bahwa terdapat $21 \%$ anggota keluarga juga terinfeksi sistiserkosis (close contact). Hal ini kemungkinan disebabkan oleh karena telur Taenia solium yang berada di lingkungan berasal dari penderita taeniasis, sehingga penderita taeniasis merupakan kunci yang terpenting dalam penularan sistiserkosis. ${ }^{1}$

Faktor lain yang mendukung adanya sistiserkosis pada anggota keluarga penderita sistiserkosis adalah berat ringannya sistiserkosis, transmisi fekal oral, faktor ekonomi atau kemiskinan, dan kemampuan menemukan sumber infeksi diantara anggota keluarga. ${ }^{16}$ Penelitian yang dilakukan Banerjee et al dalam Prasad et al ${ }^{17}$ menunjukkan bahwa 78\% anak-anak dari peternak babi mengeluarkan telur Taenia solium melalui fesesnya. Penelitian yang dilakukan oleh Subahar et al, ${ }^{14} \mathrm{di}$ Kabupaten Jayawijaya Propinsi Papua dengan menggunakan sampel serum menunjukkan bahwa di daerah endemis semua penderita taeniasis mengkontaminasi lingkungan, seorang dapat terinfeksi penyakit tersebut dari anggota keluarga sekomplek rumah (silimo) maupun dari lingkungannya yang tercemar telur Taenia solium 
oleh penderita taeniasis dari komplek lain. Penelitian Gracia-Noval et al, ${ }^{18}$ di Guatemala menunjukkan bahwa prevalensi taeniasis solium dan sistiserkosis lebih tinggi pada kelompok perempuan dibandingkan dengan laki-laki, namun secara statistik tidak ada perbedaan yang bermakna.

\section{TRANSMISI DAN SIKLUS HIDUP}

Telur atau proglotid gravid Taenia $s p$ dapat bertahan hidup selama beberapa hari sampai beberapa bulan di tanah dan menjadi infektif apabila tertelan makanan yang terkontaminasi. ${ }^{19}$ Manusia biasanya tertelan telur atau proglotid gravid cacing pita pada sayuran dan buah-buahan yang terkontaminasi atau dapat langsung dari tanah. Manusia juga dapat terinfeksi dari air yang terkontaminasi telur cacing pita.,

Taenia solium hidup di usus halus untuk mendapatkan kebutuhan nutrisi hidupnya, ${ }^{7}$ bagian proglotidnya yang sudah matang mengandung sel telur yang telah dibuahi (embrio) akan keluar bersama-sama feses manusia, ${ }^{3,7,8}$ dan menjadi infektif. ${ }^{3}$ Apabila telur T. solium termakan oleh babi, kemudian sampai pada usus maka dindingnya dicerna, embrio heksakan (onkosfer) akan keluar dari telur menembus dinding usus halus dan masuk ke saluran getah bening atau darah, ${ }^{4}$ kemudian akan difiltrasi keluar otot lurik membentuk kista dan akan membesar membentuk gelembung yang disebut sistiserkus selulosa. ${ }^{4,19}$ Sistiserkus biasanya ditemukan di otot lidah, punggung, pundak babi, ${ }^{4}$ otot jantung, hati, dan otak ${ }^{3}$ serta dapat bertahan hidup selama beberapa tahun pada hewan. ${ }^{19}$

Pada manusia, T. solium kebanyakan ditemukan pada jaringan subkutaneus, otot skelet, mata, dan otak. Periode inkubasi sistiserkosis oleh T. solium 10 hari sampai 10 tahun. ${ }^{3}$ Laporan penelitian dalam Zammarchi et al, ${ }^{11}$ menunjukkan bahwa 60 tentara Inggris yang baru pulang dari India menderita sistiserkosis setelah 2-5 tahun kemudian. Seseorang bisa menderita taeniasis/sistiserkosis melalui makanan dengan memakan daging yang mengandung cacing gelembung yang terdapat pada daging babi mentah atau yang dimasak tidak matang, ${ }^{11,19}$ kemudian skoleksnya keluar dari cacing gelembung dengan cara evaginasi dan melekat pada mukosa usus halus yeyunum dan menjadi dewasa dalam waktu 5-12 minggu., ${ }^{3,4}$ Taenia solium dewasa menghasilkan 1.000 proglotid yang berisi sekitar 50.000 telur tiap proglotid gravid ${ }^{4}$ dan telurnya keluar melalui celah robekan ${ }^{4}$ kemudian keluar bersama feses melalui anus ( rata-rata 6 telur perhari). ${ }^{14}$

Cacing pita dewasa berisi skoleks, hidup dan menyerang usus halus. Cacing pita dewasa yang terdapat pada usus manusia dapat menginfeksi manusia tersebut melalui telur cacing pita yang terdapat pada feces sendiri, dan menimbulkan sistiserkosis. ${ }^{3}$ Adanya gerakan peristaltik usus dapat menimbulkan autoinfeksi, tetapi tidak selalu terjadi. ${ }^{3,11}$

Sistiserkosis dapat terjadi apabila telur cacing T. solium tertelan misalnya pada orang dengan higiene buruk yang menderita taeniasis dengan atau tanpa gejala mengeluarkan telur cacing di fesesnya dan dapat mengkontaminasi lingkungan sekitarnya. Hal inilah yang menyebabkan penyebaran sistiserkosis bagi dirinya sendiri maupun orang lain. ${ }^{19}$

\section{GEJALA KLINIS}

Kasus taeniasis pada manusia bisa tanpa gejala (asimptomatis) ataupun hanya sedikit menimbulkan gejala. ${ }^{20}$ Gejala klinis dapat timbul sebagai akibat iritasi mukosa usus atau toksin yang dihasilkan cacing. Gejala tersebut antara lain rasa tidak enak pada lambung, mual, badan lemah, berat badan menurun, diare, sakit kepala, konstipasi (sukar buang air besar) dan nafsu makan menurun. ${ }^{8}$ Gejala tersebut dapat disertai dengan ditemukannya proglotid cacing yang bergerak-gerak lewat dubur bersama atau tanpa tinja ${ }^{4}$ sehingga secara psikologis penderita dapat merasa cemas dan gelisah. ${ }^{8,20}$ Gejala berat dapat terjadi apabila proglotid berpindah ke organ lain seperti apendiks, uterus, saluran empedu, dan nasofaringeal, dan dapat menyebabkan apendisitis, kolangitis, atau sindrom lain. ${ }^{3}$

Gejala sistiserkosis bervariasi tergantung dari lokasi, jumlah larva, ${ }^{3,4}$ dan respon pejamu. ${ }^{4}$ Kebanyakan gejala sistiserkosis yang timbul merupakan hasil dari inflamasi degenerasi larva atau efek dari massa parasit. ${ }^{3}$ Sistiserkosis dapat tanpa gejala $^{4,20}$ apabila hanya terdapat sedikit lesi dan terletak di lokasi yang tidak strategis misalnya di otot, atau beberapa daerah di otak, tetapi tetap bisa didiagnosa dengan sistiserkosis. ${ }^{4}$ Larva di otak atau mata dapat menimbulkan gejala berat, bersifat 
neurotropik, sehingga ditemukan di jaringan saraf atau neurosistiserkosis ${ }^{14}$ yang merupakan sistiserkosis berat. ${ }^{3}$ Pada beberapa kasus, gejala dapat menimbulkan bahaya. Apabila terjadi tiba-tiba, hal ini disebabkan oleh karena adanya blok cerebrospinal fluid (CSF) akibat sistiserkus. Kejang merupakan manifestasi utama neurosistiserkosis (70$90 \%)^{3,4}$ selain sakit kepala kronik. ${ }^{3}$

Penelitian yang dilakukan oleh Urthy et al dalam Rajhsekar, ${ }^{10}$ menunjukkan bahwa dari 2.531 pasien yang menderita epilepsi terdapat 10,4\% menderita sistiserkosis, sedangkan penelitian Sawhney et al menunjukkan bahwa 31\% penderita neurosistiserkosis menimbulkan kejang. Gejala lain adalah peningkatan tekanan intrakranial (mual dan muntah), gangguan status mental termasuk psikosis ${ }^{3,4}$ vertigo, ataksia, demensia, dan gejala fokal neurologis ${ }^{3,20}$ bahkan kematian. ${ }^{20}$ Pasien yang menderita sistiserkosis dapat juga memperlihatkan tanda-tanda seperti benjolan di bawah kulit, dan penderita sistiserkosis otak seringkali mengalami luka bakar. ${ }^{14}$ Penelitian Simanjuntak di Papua dalam Swacita, ${ }^{21}$ menunjukkan bahwa dari 160 orang yang diperiksa $66,3 \%$ positif menderita taeniasis/ sistiserkosis; 28,1\% penderita sistiserkosis menunjukkan gejala klinis adanya benjolan di bawah kulit yang bisa dilihat dan disentuh, dan 18,8\% dari mereka adalah pasien yang menunjukkan gejala epilepsi.

\section{DIAGNOSIS}

Diagnosis taeniasis dapat ditegakkan dengan cara anamnesis, untuk menanyakan riwayat pernah mengeluarkan proglotid cacing pita, dan ditemukannya telur atau proglotid dalam tinja. ${ }^{4,8}$ Telur cacing pita dapat ditemukan di sekitar anus. Telur Taenia sp tidak dapat dibedakan. Enzyme-Linked Immunosorbent Assay (ELISAs) dan Polymerase Chain Reaction (PCR) dapat digunakan untuk membedakan jenis telur Taenia $s p$ dan dapat digunakan untuk membedakan proglotid Taenia $s p .{ }^{3}$ Tinja yang diperiksa adalah tinja sewaktu berasal dari defekasi spontan. Sebaiknya diperiksa dalam keadaan segar, bila tidak memungkinkan tinja tersebut diberi formalin 5-10\% sebagai pengawet. ${ }^{14}$

Diagnosis sistiserkosis dapat dilakukan dengan cara ekstirpasi benjolan, radiologis (CT scan atau Magnetic Resonance Imaging (MRI), deteksi antibodi seperti teknik ELISA, Western Blot (EIBT), uji hemaglutinasi, deteksi coproantigen pada tinja, dan deteksi DNA dengan teknik PCR. ${ }^{4}$ Pemeriksaan serologi terhadap sistiserkosis perlu didukung dengan pemeriksaan tinja dengan metode mikroskopis maupun deteksi coproantigen untuk mengetahui apakah penderita sistiserkosis juga menderita taeniasis sehingga dapat menjadi sumber penularan bagi dirinya sendiri maupun orang lain disekitarnya (worm carriers). ${ }^{14}$

\section{PENGOBATAN}

Pengobatan penderita taeniasis dapat diberikan obat niklosamid atau prazikuantel per oral. ${ }^{2,4}$ Praziquantel dapat membunuh dan menghancurkan cacing pita dewasa di saluran pencernaan usus atau sistiserkus pada jaringan parental. Dosis praziquantel $50 \mathrm{mg} / \mathrm{kg}$ BB dosis tunggal atau dosis terbagi tiga selama 15 hari efektif untuk sistiserkosis. Obat pilihan lain adalah albendazole $15 \mathrm{mg} / \mathrm{kg}$ BB/hari dalam dosis tunggal atau terbagi tiga selama 7 hari; Mebendazole 2 x $200 \mathrm{mg} /$ hari selama 4 hari. Pengobatan biasanya sangat efektif, tetapi apabila proglotid mulai tampak lagi dalam tinja atau bergerak dari anus, maka diperlukan pengobatan ulangan. Tinja diperiksa kembali setelah 3 dan 6 bulan untuk memastikan bahwa infeksi telah terobati. ${ }^{8}$

Pengobatan sistiserkosis selain pemberian oral juga dapat dilakukan pembedahan ${ }^{3,4}$ untuk sistiserkus pada lokasi seperti mata, otak, dan tulang belakang. ${ }^{3}$ Pengobatan neurosistiserkosis aktif memerlukan berbagai pengobatan tambahan untuk mengatasi kista hidup, gejala, dan reaksi akibat pengobatannya sendiri. Obat yang digunakan adalah praziquantel (50$100 \mathrm{mg} / \mathrm{kg}$ dalam 3 dosis terbagi) selama 14 hari, albendazol (15 mg/kg bb dalam 2-3 dosis terbagi) selama 8 hari, kortikosteroid (10-30 mg dexametason perhari, atau $60 \mathrm{mg}$ prednison dilanjutkan dengan tappering off, dan obat antikonvulsan seperti fenitoin atau fenobarbital. ${ }^{4}$

\section{PENCEGAHAN}

Pencegahan penyakit taeniasis dan sistiserkosis dapat dilakukan dengan cara:

1. Mengobati penderita (praziquantel, (mebendazole, albendazole, niclosamide, dan 
atabrin) untuk menghilangkan sumber infeksi dan mencegah terjadinya autoinfeksi dengan larva cacing.

2. Memelihara kebersihan lingkungan dengan buang air besar tidak sembarangan (menggunakan jamban keluarga) sehingga feses manusia tidak dimakan oleh sapi/babi dan tidak mencemari tanah atau rumput. ${ }^{5,8}$

3. Pengaturan pemeliharaan sapi babi seperti: memelihara sapi pada tempat yang tidak tercemar atau membuat kandang sapi agar tidak dapat berkeliaran. ${ }^{8}$

4. Pemeriksaan daging oleh dokter hewan di RPH (Rumah Pemotongan Hewan), sehingga babi mengandung kista tidak sampai dikonsumsi masyarakat (kerjasama lintas sektor dengan dinas peternakan). ${ }^{5,8}$

5. Daging yang mengandung kista tidak boleh dimakan.

6. Menghilangkan kebiasaan makan makanan yang mengandung daging setengah matang atau mentah. $^{8}$

7. Memasak daging babi di atas suhu $50 \mathrm{C}$ selama 30 menit untuk mematikan larva sistiserkus atau menyimpan daging babi/sapi pada suhu $10 \mathrm{C}$ selama 5 hari. ${ }^{5,8}$

8. Memberikan vaksin pada hewan ternakbabi (penggunaan crude antigen yang berasal dari onkosfer, sistisersi, atau cacing dewasa Taenia solium).

9. Memberikan cestosida (praziquantel, dan oxfendazole) pada hewan ternak babi. ${ }^{8}$

10. Menjaga kebersihan diri seperti mencuci tangan dengan sabun setelah buang air besar, sebelum makan $^{5,19}$ atau mengganti popok bayi ${ }^{19}$, mengolah makanan serta rajin mandi. ${ }^{5}$

11. Mencuci sayuran dan buah-buhan sebelum dimakan

12. Mengajari anak untuk mencuci tangan dengan sabun. ${ }^{19}$

\section{KESIMPULAN}

Taeniasis solium disebabkan oleh infeksi cacing pita dewasa Taenia solium, sedangkan sistiserkosis disebabkan oleh larva Taenia solium. Taeniasis/ sistiserkosis timbul karena memakan daging babi mentah atau setengah matang dan buruknya sanitasi atau higiene. Sistiserkosis dapat menyebabkan neurosistiserkosis yang dapat menimbulkan gejala berat seperti kejang, peningkatan tekanan intrakranial, gangguan status mental sampai kematian. Pencegahan penyakit taeniasis/sistiserkosis dapat dilakukan dengan menghindari makan daging babi mentah atau kurang matang, dan menjaga kebersihan diri dan lingkungan.

\section{DAFTAR PUSTAKA}

1. WHO. The control of neglected zoonotic diseases-community-basedinterventions for prevention and control; 2011[diakses 1 Juni 2018]. Available from:http://apps.who.int/iris/bitsream/ $\mathrm{h}$ a n d l e / $10665 / 44746 /$ 9789241502528_eng.pdf?sequence=1\&isAllowed=y.

2. WHO. Taenia solium taeniasis/cysticercosis diagnostic tools. Report of a stakeholder meeting, Geneva; 2016 [diakses 2 Juni 2018]. Available from: http://apps.who.int/iris/bitstream/handle/ $\begin{array}{lllllllllllll}1 & 0 & 6 & 6 & 5 & / & 2 & 0 & 6 & 5 & 4 & 3 & /\end{array}$ 9789241510516_eng.pdf?sequence=1.

3. The Center for Food Security\& Public Health. Taenia infection:taeniasis, cysticercosis, neurocysticercosis, coenurosis, neurocoenurosis. 2005 [diakses 1 Juni 2018]. Available from:www.cfsph.iastate.edu/IICAB.

4. Hadidjaja P. Cestoda. Dalam: Sutanto I, Ismid IS, Sjarifudin PK. Eds. Parasitologi Kedokteran. Ed: 4. Jakarta: Balai Penerbit FKUI; 2016:7390.

5. Sandy S. Kajian aspek epidemiologi taeniasis dan sistiserkosis di Papua. Jurnal Penyakit Bersumber Binatang. 2014; 2(1):1-14.

6. Yanagida, T, Sako Y, Nakao, M, Nakaya, K, Ito, A. Taeniasis and cysticercosis due to Taenia solium in Japan. Parasites \& Vectors. 2012:5:18.

7. Suriawanto N, Guli MM, Miswan. Deteksi cacing pita (Taenia soliumL)melalui uji feses pada masyarakat desa Purwosari Kecamatan Torue Kabupaten Parigi Moutong Sulawesi Tengah. Biocelebes. 2014;8(1):17-28. 
8. Setiyani E. Taenia saginata. Balaba. 2011;7(2):578.

9. Aung AK, Spelman DW. Taenia solium taeniasis and cysticercosis in Southeast Asia. Am. J. Trop. Med. Hyg. 2016;94(5):947-54.

10. Subahar R, Hamid A, Purba W, Widarso, Ito A, Margono SS. Taeniasis/sistiserkosis di antara anggota keluarga di beberapa desa, Kabupaten Jayawijaya, Papua. Makara Kesehatan. 2005;9(1): 9-14.

11. Wandra, T, Sri S Margono, S.S, Gafar, M.S, Saragih, J.M, Sutisna, P, Nyoman, S, Dharmawan, N.S. et al. Taeniasis/Cysticercosis in Indonesia 1996-2006.2003;38(1):140-3. (diakses tanggal 20 Juni 2018). Available from: http:// www.tm.mahidol.ac.th/seame o/2007-38-suppl1/38suppl1-140.pdf.

12. Widarso HS, Margono SS, Purba WH,Subahar R. Prevalensi dan distribusi taeniasis dan sistiserkosis. Makara Kesehatan. 2011;7(2):5758.

13. Irianto K. Parasitologi medis. Cetakan kesatu . Bandung: Alfabeta, 2013: 327-36.

14. Subahar R, Hamid A, Purba W, Widarso, Ito A, Margono SS. Taeniasis/sistiserkosis di antara anggota keluarga di beberapa desa, Kabupaten Jayawijaya, Papua. Makara Kesehatan. 2005;9(1): 9-14.

15.Wandra, T, Sri S Margono, S.S, Gafar, M.S, Saragih, J.M, Sutisna, P, Nyoman, S, Dharmawan, N.S. et al. Taeniasis/Cysticercosis in Indonesia 1996-2006.2003;38(1):140-3. (diakses tanggal 20 Juni 2018). Available from: http:// www.tm.mahidol.ac.th/seame o/2007-38-suppl1/38suppl1-140.pdf.
16. Sorvillo F, Wilkins P, Shafir S, Aeberhard S. Public health implications of cysticercosis acquired in the United States. Emerg Infect Dis.2011;17(1):16.

17.Prasad Et KN, Prasad A, Gupta RK, Pandey CM, Singh U. Prevalence and associated risk factors of Taenia solium taeniasis in a rural pig farming community of north India. Transactions of the Royal Society of Tropical Medicine and Hygiene. 2007;101:1241-7.

18. Garcia-Noval J, Allan JC, Pletes C. Epidemiology of Taenia solium taeniasis and cysticercosis in two rural Guatemalan Communities. Am J Trop Med Hyg. 1996; 55: 282-289.

19.Center for Disease Control. Taeniasis. 2013 [diakses tanggal 12 Juni 2018]. Available from: https://www.cdc.gov/parasites/taeniasis/ index.html.

20.Laranjo-Gonzaìlez, Devleesschauwer B, Trevisa C. Epidemiology of taeniosis/cysticercosis in Europe, a systematic review: Western Europe Parasites \& Vectors. 2017;10(349) :2-4. 10:349 DOI 10.1186/s13071-017-2280-8.

21.Swacita IB, Agustina KK, Polos IW, Fitriani S, Natalia. Survei seroprevalensi Taenia soliumsistiserkosis di Kabupaten Mimika, Papua. Buletin Veteriner Udayana. 2015;7(2):172-78. 